\title{
NAWACITA AND THE LAW ENFORCEMENT OF CIVIL STATE APPARATUS IN CONSTITUTIONAL LAW PERSPECTIVES IN INDONESIA
}

\author{
Jawade Hafidz ${ }^{1}$ \\ UNISSULA, Semarang, Central Java, Indonesia \\ jawadehafidz60@gmail.com
}

\begin{abstract}
"Nawacita" and Constitutional Law needs to be a legal approach to make improvements to the legal system, in order to encourage enforcement of the law with justice, then at least have to involve three pillars consisting of: (1) the substantive law (legal substance), which include legislative reform; (2) legal structure (law structure), including human resources law-enforcement officers (human resource), entered in it anyway coordination among law enforcement officers; and (3) the legal culture (legal culture), both culture and public law enforcement officers or citizens in general.

Then, constitutional law and can be answered correctly, can be practiced within their Constitutional Act and may be unenforceable government in running the government. The key factor to keep in mind is eliminating ego-sectoral government agencies. Do not stop until the Act, a similar effort was also made to the laws which are in the executive area, such as government regulations, a presidential decree and ministerial regulation
\end{abstract}

Keywords : Nawacita, law enforcement, civil states apparatus, constitutional law

\section{Introduction}

The beginning of reformation, there has been done a lot of mapping and analysis to save the "law" as one of the main pillars of this country. However, in practice, until now it has not shown a comprehensive and holistic improvement. This is happened since in encouraging legal reform, the involved parties are more likely to use a tactical approach to reform. Reformation is only done by fixing or patching defects, without making a thorough investigation and formulation, and forms a major update design, the improvements are often adhoc or patchy. ${ }^{2}$

We go in to the fundamental question; What is "Nawa" "Cita"? or "Nawacita" what is the definition? Typically, it is a general term that is absorbed from Sanskrit, nawa (nine) and cita (hope, agenda, desire).

In the context of Indonesian politics in the run up to the 2014 Presidential Election, this term refers to the vision and mission used by presidential candidates and vice-presidential candidates Joko Widodo and Jusuf Kalla containing the couples' government agenda. ${ }^{3}$ In the vision-mission was presented nine main agenda to continue the spirit of struggle and ideals Sukarno known as Trisakti, namely sovereign politically, independently in the economy, and personality in culture.

If we look at and refer to the source of the General Election Commission, there are nine basic items in the government of Joko WidodoJusuf Kalla, as follows;

1. Bringing the country back to protect the entire nation and provide security to all citizens, through active free foreign policy, reliable national security and the integrated defense of Tri Matra state based on national interests and strengthening identity as a maritime country.

Lecturer at Faculty of Law, UNISSULA. Chief of APPSIHI.

2 See Wahyudi Djafar, Menjejaki Kembali Problematika Hukum Indonesia, dalam Asasi Elsam, November-Desember 2010.

3 See in the vision and mission Capres-Cawapres Joko Widodo-Jusuf Kalla when they register in KPU. http://kpu. go.id/koleksigambar/VISI MISI Jokowi-JK.pdf, accessed on 5 May 2015. 
2. Making governments not absent by building clean, effective, democratic, and reliable governance by giving priority to restoring public confidence in democratic institutions by continuing to consolidate democracy through party system reform, elections and representative institutions.

3. Building Indonesia from the periphery by strengthening the regions and villages within the framework of the unitary state.

4. Refusing weak countries by reforming system and law enforcement which is free of corruption, dignity, and trust.

5. Improving the quality of human life of Indonesia through improving the quality of education and training with the program "Indonesia Smart"; as well as improving people's welfare with the "Indonesia Kerja" and "Sejahtera" programs by encouraging land reform and a 9-hectare land tenure program, the Kampung Seret home program or subsidized low-cost housing and social security for the people in 2019.

6. Increasing people's productivity and competitiveness in international markets so that the nation of Indonesia can advance and rise with other Asian nations.

7. Realizing economic independence by mobilizing domestic strategic sectors of the economy.

8. Revolutionizing the nation's character through the policy of reorganizing the national education curriculum by promoting the aspect of civic education, which puts proportional aspects of education, such as teaching the history of nation-building, patriotic values and love of the country, the spirit of state defenses and character in the curriculumeducation of Indonesia.

9. Strengthening diversity and strengthening Indonesia's social restoration through policies to strengthen diversity education and create inter-community dialogue spaces.

What is the implementation of Nawacita in the Jokowi-JK government in the past one or two years? Within a year of Jokowi-JK's administration there is also criticism and dissatisfaction with the Jokowi-JK government. In responding this, we are reflecting on what the government has done instead of criticizing the current conditions, we assess how the government's performance in one year.

At the beginning of his presidency, President Jokowi-JK always upheld the nawacita. It begins with a breakthrough in choosing ministers involving the KPK (Corruption Eradication Commission) in selecting ministers, point of view to realize the quality of life of the people translated in Jokowi-JK government by realizing the Kartu Sakti (Powerful Card) program namely Kartu Indonesia Sehat (Indonesia Health Card), Kartu Indonesia Smart, and Kartu Keluarga Sejahtera (Prosperous Family Card). In the field of law enforcement and human rights, president Joko Widodo-Jusuf Kalla has also taken decisive action in the form of execution of death against a number of drug dealers. The government of Joko Widodo-Jusuf Kalla also "ferocious" drowns foreign ships that steal fish. Public satisfaction of Jokowi-JK government in the field of education and health reaches $60 \%$ (Poltracking Indonesia Research).

This means that the public welcomes Jokowi$J K$ performance in that field. The level of community satisfaction on Jokowi's performance reached $46.0 \%$, the level of community satisfaction over the performance of vice president Jusuf Kalla $42.1 \%$, the level of public satisfaction of the minister's performance $36.3 \%$ (Indo Barometer / IB; September 2015). ${ }^{4}$

From the data above, there is something interesting and striking whether it is real or not? However, from the other side there is satisfaction of social index of society which reaches $40 \%$ more in performance of Jokowi-JK government. Now let's see if it represents the nation's law matters and good constitutional law?

From the side the government claims that the performance and data say the real condition. In the field of law, the achievements over a period of 2 years is firstly, Deregulation of Regional Regulations by revoking 3,143 local regulations;

4 Let's look at the full source on http://www.kompasiana. com/rickoricardo/keberhasilan-nawacita-jokowi-jksatu-tahun-pemerintahan_562cb5dbd27a6141076e 3fb1, accessed on 14 January 2017 at 11.15 wib. 
Secondly, Police Performance is improving with indicators of crime rate decline from 373,636 in 2015 to 165,147 in 2016 (as of June) and the number of traffic accidents decreased significantly both the number of accidents and casualties, in 2016 fell to 1,947 cases from the previous year in 2015 of 2,228 case; third, the Attorney General's Office managed to save state finances of Rp. 14.2 trillion during January-September 2016; Fourth, TaxAmnesty Program as a breakthrough in tax law until October has succeeded in reaching a ransom of $\mathrm{Rp} 97.15$ trillion or $60 \%$ of the target Rp165 trillion; fifth, the arrest of fugitive corruptor Samadikun Hartono (BLBI 1998 case) in China on April 14, 2016, Totok Ary Prabowo (former Temanggung Regent) in Cambodia on September 12, 2015 and Hartawan Aluwi (Case Bank Century) in Singapore on April 22, 2016. ${ }^{5}$

Meanwhile, Professor of Constitutional Law from Andalas University, Saldi Isra, stated that for this two years Jokowi-JK government has not focused in the field of law. In the first year, the government was busy doing a political consolidation such as government relations with the House of Representatives on a political map of supporters and not a supporter of government. The second year, the government focused on the economic field marked the publication of the package of economic policy. ${ }^{6}$

The legal issues targeted in the last two years are merely tangent to economic activity and investment. "The government is cutting regulations that hamper the economy and inward investment that is worked out by law."

UGM's Constitutional Law expert Zainal Arifin Mochtar looks at the way President Jokowi elects the cabinet to show the government surrender to the interests of political parties (political parties). It is a goal of political consolidation, so that the legal field has not become the main focus of the

5 If we look from the source of the Polhukam ministry as follows; https://polkam.go.id/perwujudan-nawacitadi-bidang-politik-hukum-dan-keamanan-untukmemulihkan-kepercayaan-publik-memberikankeadilan-dan-kepastian-hukum/ accessed on 14 January 2017 at 11.26 wib.

6 http://www.hukumonline.com/berita/baca/ It5805f6a92b7b4/dua-tahun-jokowi-jk--hukumterabaikan, accessed on pada 14 Januari 2017 at 11.26 wib. government ${ }^{7}$. In terms of scientific study there is an interesting example: the results of a survey conducted by the Indonesian Legal Roundtable (ILR) in 2015 showed Indonesia Legal Country Index 2015 increased to 5.32 from the previous year 5.18. The last few years ILR launched Indonesia Legal Country Index with various indicators. ${ }^{8}$

Are the legal advantage and disadvantage in the series of Nawacita and Constitutional Law already achieving the targets that have been intended by the government? Can our legal capacity in government now remain unchanged from the system of legal authoritarianism? Indeed, a sporadic settlement in legal remedies cannot cure all legal issues in the Jokowi-JK period today. It needs a thorough touch in its improvement, namely the improvement of the legal system itself. It uses the legal system approach proposed by Lawrence Friedmen (1998). In order to improve the legal system and to encourage fair law enforcement, it must at least involve three pillars consisting of: (1) legal substance, legislation reform; (2) the legal structure, including human resources-the human resource apparatus, includes the coordination among law enforcement officials; and (3) legal culture (legal culture), whether the culture of law enforcers or the public or citizens in general. ${ }^{9}$ Ibid.

8 The survey is based on the five principles used in the survey: Legal Governance, Formal Legality, Independent Judiciary, Access to Justice and Human Rights. The study used expert survey methods and document collection in 20 provinces in Indonesia. Of the 5 principles surveyed, the human rights field got the lowest score of 3.82. There are 6 indicators used to assess the Indonesian Legal Status Index 2015 for the human rights field, namely the right to life, the right to be free from torture, the right not to be enslaved, the right not to be imprisoned under contractual obligations, the right not to be punished for non- the right to freedom of thought, religion and belief. The government needs to revise its policy not only to focus economic affairs, but also to make human rights as mainstream. The Indonesia Legal Status Index Survey 2015 shows the various indicators that exist in the human rights principle of its value plummeted. Of the 6 indicators in the human rights principle, there are 3 lowest values of guarantee for the right to be free from torture (2.99), guarantee of the right to life (3.51) and the guarantee of the right not to be imprisoned on the basis of contractual obligations (3.75) .Ibid.

9 Lawrence M. Friedman, American Law: An Introduction, (New York: W.W.Norton, 1998). 
Responding to the challenge of the above problems, the Jokowi-JK government then in one of its seven government missions affirmed the desire to "Create a developed, equitable and democratic society based on the rule of law". The mission will be embodied with a strategic agenda to reform the law enforcement system that is free of corruption, dignity and trust, and respect for human rights, and the just settlement of cases of past human rights violations (fourth agenda of Nawacita). The priority agenda is further downgraded to 42 main priorities that are part of the effort to achieve political independence. These 42 priorities include reform of law enforcement systems, protection of marginalized groups, and respect, protection and enforcement of human rights. However, in the preparation of this document, we will only focus on the 17 priorities within the Joy, which are part of the legal development agenda and the apparatus, as defined in Chapter 7 of Book II of the RPJMN 2015-2019. ${ }^{10}$

There are several steps that must be carried out by the government, especially Kemenkuham
(The Ministry of Law and Human Right), as Elsam once delivered;

1. The need to identify the gap between Nawacita and RPJMN, both at the strategic and indicator level, to formulate it in the annual work plan (RKP), in order to minimize the potential for failure to achieve the mission's vision;

2. The importance of checking and inventorying plans and indicators outlined in the development sector matrix, which is the institutional responsibility, to avoid inconsistencies with Nawacita and RPJMN;

3. The need to develop instruments / tools that can measure the extent of progress of any development plan implementation, in support of achievement; and

4. The need to make an assessment of the overall development plan, using a human rights approach, to examine the extent of potential human rights violations in any program and developmentagenda. ${ }^{11}$

\begin{tabular}{|c|c|c|c|}
\hline No & $\begin{array}{l}\text { Nawacita } \\
\text { Strategy }\end{array}$ & RPJMN Strategy & Note \\
\hline 1 & $\begin{array}{l}\text { The reform } \\
\text { of law } \\
\text { enforcement } \\
\text { system }\end{array}$ & $\begin{array}{l}\text { 1. Enhancement of law enforcement: } \\
\text { 2. Increased integration within the } \\
\text { Criminal Justice System } \\
\text { 3. Easy and Fast Civil Law System } \\
\text { Reform } \\
\text { 4. Human Resource Development } \\
\text { Law Enforcement Apparatus } \\
\text { 5. Legal Services }\end{array}$ & $\begin{array}{l}\text { The enforcement of law enforcement } \\
\text { systems in Nawacita is further directed } \\
\text { to the reform of the prison system, } \\
\text { while the RPJMN also involves reform } \\
\text { of the civil law system, as well as the } \\
\text { development of human resources of } \\
\text { law enforcement apparatus and legal } \\
\text { services }\end{array}$ \\
\hline 2 & $\begin{array}{l}\text { Protection } \\
\text { of children, } \\
\text { women and } \\
\text { and marginal } \\
\text { community } \\
\text { groups }\end{array}$ & $\begin{array}{l}\text { 1. Implementation of the criminal } \\
\text { justice system of children } \\
\text { 2. The handling of violence against } \\
\text { women and children, through } \\
\text { a strategy of strengthening the } \\
\text { coordination mechanism of the law } \\
\text { enforcement apparatus }\end{array}$ & $\begin{array}{l}\text { Marginal community groups are the } \\
\text { ones that will get priority protection } \\
\text { for vulnerable groups in Nawacita, } \\
\text { while the RPJMN only accommodates } \\
\text { children and women. In addition, } \\
\text { in the RPJMN, child protection and } \\
\text { women's protection strategies become } \\
\text { part of strategic improvements in law } \\
\text { enforcement quality }\end{array}$ \\
\hline
\end{tabular}

11 Nawacita and RPJMN as a Unity Development Plan: The field of Human Rights Law, prepared by the Institute for Policy Research and Advocacy (Institute for Policy Research and Advocacy) pada 11 Maret 2015.

12 Zainal Abidin, Catatan Elsam Terkait RPJMN 2015-2019 Di Bidang Hukum Dan HAM, 11 Nopember 2015, dalam http://elsam.or.id/2015/03/catatan-elsam-terkait-rpjmn-2015-2019-di-bidang-hukum-dan-ham/ accessed on 14 Januaryi 2017 at 12.15 wib 


\begin{tabular}{|c|c|c|c|}
\hline No & Nawacita & RPJMN Strategy & Note \\
\hline 3 & $\begin{array}{c}\text { Respect } \\
\text { for human } \\
\text { rights and } \\
\text { just settling } \\
\text { cases of past } \\
\text { human rights } \\
\text { violations }\end{array}$ & $\begin{array}{l}\text { 1. Harmonization and evaluation of } \\
\text { Human Rights regulatory authority } \\
\text { 2. Enforcement of OHAM, through } \\
\text { the implementation, monitoring, } \\
\text { evaluation and reporting of HAM } \\
\text { 3. Education Human of Rights } \\
\text { 4. The establishment of Komisiadhoc } \\
\text { to facilitate the process of disclosure } \\
\text { of human rights violations in the past } \\
\text { and the restoration of sacrifices }\end{array}$ & $\begin{array}{l}\text { In the context of the settlement of } \\
\text { human rights violations, Nawacita } \\
\text { opens the opportunity for completion } \\
\text { with all the mechanisms (court, truth- } \\
\text { telling commission and victim recovery), } \\
\text { while in the RPJMN opens opportunities } \\
\text { for the establishment of an ad hoc } \\
\text { committee for the disclosure of the truth } \\
\text { and the recovery of victims. There is a } \\
\text { consensus in the development matrix, } \\
\text { because it opens the possibility to } \\
\text { hold a court. In addition, in the context } \\
\text { of human rights education, Nawacita } \\
\text { directs the integration of human rights } \\
\text { education in the curriculum of primary } \\
\text { and secondary education, while the } \\
\text { RPJMN only emphasizes human rights } \\
\text { education in the state. }\end{array}$ \\
\hline
\end{tabular}

Table: As a reflection of Nawacita comparative table data and human rights law. ${ }^{12}$

\section{View the "Unruly" Legal Agenda}

Let us compare the stagnant and ongoing legal position, is it equivalent to the 2016 Government Work Plan (RKP) as the second year of the National Medium Term Development Plan (RPJMN) 2015-2019. It is the continuity of planned and systematic and implemented development efforts done by each and all components of the nation by utilizing various resources that are available optimally, efficiently, effectively and accountably with the ultimate goal to improve the quality of human life and society sustainably. ${ }^{13}$

As mandated by Law Number 25 Year 2004 on the National Development Planning System, RKP contains development priorities, macroeconomic framework design, ministry I institutional programs, cross-ministries, territories in the form of a regulatory framework and indicative funding framework. ${ }^{14}$ Where is the legal liaison with the government's performance wrapped in the granary of the nawacita?

12 Ibid

13 The direction of nation-building is also laid on the principles set forth in the mandate in the preamble of the 1945 Constitution, namely (1) To protect the whole nation and all the blood; (2) Promoting public welfare; (3) To educate the life of the nation; (4) Participate in maintaining world order based on freedom, social justice and lasting peace.

14 Attachment of Presidential Regulation Number 60 Year 2105 Concerning Government Work Plan 2016, Theme: Accelerating Infrastructure Development To Strengthen the Foundation of Quality Development, p. 1-1.

15 Saldi Isra, Hukum Yang Terabaikan, Kompas, 22 Juli 2016 
in the internal prosecutor's office during the Jokowi era?. Simple question, but certainly far from simple answer it completely. If from the beginning Jokowi outlined the direction of the prosecutor's reform, it would have been much easier to evaluate the performance of the Attorney General. As an institution under President, for example, according to Nawacita's 39th law enforcement priority agenda, Jokowi should order the Chief of Police and the Attorney General to conduct a job auction to fill a strategic position in the police and prosecutor's office. Had the written declaration of legal reform in Nawacita be presented publicly to the Chief of Police and the Attorney General, various groups concerned with police reform and the prosecutor's office had a strong reason to charge it to the Chief of Police Tito and Attorney General Prasetyo. ${ }^{16}$

Tracking the threads in Nawacita, the legal agenda is elaborated into 11 commitments, including clear, open, and legislative political legislation in the fight against corruption, human rights enforcement, environmental protection and law enforcement reform. Specifically, the eradication of corruption will be carried out consistently by strengthening the Corruption Eradication Commission. Jokowi-Kalla also promised to eradicate the judicial mafia that has long been a chronic disease of law enforcement. ${ }^{17}$

During two years of reigning, Jokowi-JK's commitment to reform legislation has not been so visible. The formation of the law still runs normally as before Jokowi-Kalla ruled. If it is now questioned, can the government prove that a law born with politics legislation is different from the previous era? It is certainly not easy to give a satisfactory answer. Let's not change the paradigm of legislation; the achievement of the Act has always been far below the national legislation program. ${ }^{18}$

The legal shrinkage is the main thread in Nawacita as we see in the data ever submitted by the ILR. It is the same if we describe the legal issues that twist the ambiguity of legal validity itself about many local law products that 16 Ibid

17 Saldi Isra, Mempercepat Agenda Hukum, Kompas 21 Oktober 2016

18 Ibid conflict with higher regulations, the sample is; government efforts to cancel 3,000 of local legal products received special appreciation among some circles. However, such a move has not been made in the comprehensive design of a comprehensive solution of legal products, especially between the central and regional governments. Regional complaints cannot be synchronous regional law products as long as the legal products produced by the central government are out of sync. Conditions are increasingly complicated because the sectoral laws also add to the shackles for the regions. ${ }^{19}$

The important note is to provide an accurate solution to the implementation of the law as follows; to inventory the applicable law for the discovery of conflicting substances. Then, when it comes to the draft law, there is no overlap with the applicable law. A key factor to note, eliminating the egosectoral between government agencies. Do not stop until the law, the same efforts are also made on legal products that are in the executive region, such as government regulations, presidential regulations, and ministerial regulations. Then, similar steps are also made to the legal products in the region. ${ }^{20}$

So, what is the law in "state-of-law" which capable of being embodied JokowiJK? While the current condition of political developments sufficiently heated up and experienced the reshuffles of his new cabinet. Indeed, it has an effect in the stabilization and maturation of the law because the law itself is always present as a product of politics; which are represented by the stakeholders through the People's Leadership Council. Are the indicators of success in the field of law above merely the imagery and the embedding of the report or how true in a legal perspective?

\section{Law of the State Civil Apparatus; Does it work?}

There is an interesting statement submitted by Menkopolhukam (Minister of Coordinating Ministry for Political, Legal and Security Affairs), Wiranto that the goal to be achieved from the

19 Ibid.

20 Ibid. 
revitalization of the law is to restore public confidence in national law. The second gives a sense of justice to the community and the third is the legal certainty for the community so that the community feels protected from the national laws already held in the community.

Again, we have to look into the government itself about the success of the achieved legal product, realized. From the side of the law that comes from the pro with the government then the issue of "law" and "security" is said to succeed with the decomposition of data as follows; ${ }^{21}$

\section{Law}

In the field of law, the government recorded 6 important achievements during the second period of Jokowi-JK government. The first achievement is deregulation of local regulations (Perda) where the Ministry of Home Affairs has revoked 3,143 perda problems.

The second achievement is the improvement of Police performance with an indicator of decreasing crime rate from 373,636 cases in 2015 , down to 165,147 cases in 2016 (per-June). In addition, there was a significant decrease in the number of traffic accidents both from the number of cases and casualties, ie in 2015 reached 2,228 cases and in 2016 decreased to 1947 cases.

Third, the success of the AGO saved state finances by $\mathrm{Rp} 14.2$ trillion during the period from January to September 2016.

TaxAmnesty's program as a breakthrough in tax law is the fourth important achievement. In the tax amnesty program, from July to October the ransom has reached $\mathrm{Rp} 97.15$ trillion or 60 percent of the Rp 165 trillion targets.

The fifth achievement was the success of capturing and repatriating fugitive corruptor Samadikun Hartono (BLBI 1998 case) in China on April 14, 2016, Totok Ary Prabowo (former Temanggung Regent) in Cambodia on 12 September 2015 and Hartawan Aluwi (Case Bank Century) in Singapore on April 22, 2016.

The sixth achievement, the government launched a gradual national legal reform. In 21 Lihat keterangan lengkapnya pada sumber: http://www.infonawacita.com/2-tahun-nawacita -memberikan-keadilan-dan-kepastian-hukum/ accessed on 14 Januari 2017 at 14.36 wib. the first phase, the government focused on five programs, namely the eradication of illegal levies, smuggling eradication, the acceleration of SIM (Driver License) management, STNK, SKCK and BPKB, the relocation of prisons and the improvement of patent, brand and design services. To support this first phase of the reform program, the government established a unit of duty clean sweep (Satgas Saber Pungli) through Presidential Decree No. 87 of 2016.

\section{Security}

In the field of security, the government recorded three important achievements during the second period of Jokowi-JK government. First, the government develops in the border area by establishing 7 State Border Post (PLBN) and its supporting facilities.

The second achievement, in the effort to prevent radicalism and terrorism with the death of Santoso leader of Mujahidin Indonesia Timur (MIT) group based in Poso, Central Sulawesi. During this period, as many as 170 police suspected members of terrorist groups.

The third achievement is the success of Indonesian foreign diplomacy to liberate Indonesian citizens who were held hostage by the Abu Sayyaf group in the southern Philippines.

"This data is true, there are six legal capabilities and three security achievements. However, the truth of the data mentioned above can be called as a success in the indicators of the Civil State Apparatus law study which still often occur legal manipulation and overlap in the appointment of a certain position.

Speaking of law in the context of State Civil Apparatus means we are talking about bureaucracy that cannot be separated from the legal context itself. Karl D Jackson considered that bureaucracy of Indonesia is a bureaucratic polity model in which there is accumulation of power in the state and removes the role of society from political space and Government. Richard Robinson and King called bureaucracy in Indonesia as a bureaucratic capitalism. ${ }^{22}$

22 Lili Romli, Masalah Reformasi Birokrasi, Jurnal Kebijakan dan Manajemen PNS, Vol. 2 November 2008. 
Whereas if we look at his opinion Hans Dieter Evers saw that bureaucratic process in Indonesia develops Parkinson and Orwel. Bureaucratic according to Parkinson's is pattern where grow the number of personnel and spread uncontrolled structural position. On the other hand, Orwel stated that bureaucracy is a bureaucratization pattern as a process of expanding the power of the Government with the intent of controlling economic, political and social activities with regulation. ${ }^{23}$

The next question arises as to whether the bureaucracy in Indonesia is not expanding becomes more efficient, but it is just opposite of the efficiency, the convoluted and the many formal rules that are not adhered to. The bureaucracy in Indonesia is also marked by the growth of employees and organizational structure and makes the bureaucracy bigger and bigger. The bureaucracy is increasingly controlling and controlling people in the political, economic and social fields.

Then, there is an empirical labeling that the Indonesian cyber capacity as it turns out is not until the site, but through the cultural approach of the Indonesian bureaucracy belongs to the patrimonial bureaucracy. The characteristics of the patrimonial bureaucracy are (1) officials are screened on the intellectual intelligence; (2) position is viewed as a source of wealth and profit; (3) officials control both political functions and administrative functions, and (4) any action directed by personal and political relations. ${ }^{24}$

Now, we re-examine the law, that in the Law of the Republic of Indonesia Number 5 Year 2014 About the State Civil Apparatus said; "That in the framework of the implementation of the nation's ideals and the realization of the objectives of the state as stated in the preamble of the 1945 Constitution of the State of the Republic of Indonesia, it is necessary to build civil apparatus of state with integrity, professional, neutral and free from political intervention, clean from corrupt practices, collusion and nepotism, and capable of providing public services for the community and able to perform the role as an adhesive element of unity and national unity

23 Ibid.

24 lbid. based on Pancasila and the 1945 Constitution of the State of the Republic of Indonesia.

Then it is clarified with the sentence; "That the implementation of civil state apparatus management has not been based on the comparison between the competencies and qualifications required by the position with the competencies and qualifications of the candidates in the recruitment, appointment, placement and promotion of the position in line with good governance";

Meaning; professions for Civil Servants and government employees with employment agreements working in government agencies consisting of Civil Servants and government employees with employment agreements appointed by civil service officers and assigned tasks in a government position or assigned to other state duties and paid under statutory regulations -invitation.

In this case, legal ownership is directed to legal practice regulated by the Ministry of Administrative Reform and Bureaucratic Reform which has the duty of conducting affairs in the field of utilizing state apparatus and bureaucratic reform in government to assist the President in organizing the State government. ${ }^{25}$ In carrying out its duties, the Ministry of Administrative Reform and Bureaucratic Reform carried out functions:

1. Formulation and determination of policies in the field of empowerment of state apparatus and bureaucratic reform;

2. Coordination and synchronization of policy implementation in the field of empowerment of state apparatus and bureaucratic reform;

3. Management of state property / property which is the responsibility of the ministry for the utilization of state apparatus and bureaucratic reform; and

25 See more detail on Presidential Regulation No. 24/2010 concerning Status, Duties and Functions of State Ministries and Organizational Structure, Duties and Functions of Echelon I of State Ministries, and see also Presidential Regulation No. 56 of 2013 on the Fourth Amendment of Presidential Regulation No. 24 of 2010 on the Position, Duties and Functions of State Ministries as well as the Organizational Structure, Task and Function of Echelon I of State Ministries. 
4. Supervision over the execution of duties within the ministry enabling the state apparatus and bureaucracy reform.

Based on the rules are already matched, but in practice that often occurs in law enforcement based on the state apparatus we always miss the momentum of weaknesses that often become a common problem, among others; (1). Corruption and abuse of authority, (2) Legislation overlap, (3) Overlapping authority, (4) Un-proportionate organization, (5) Quality and quantity of human resources Apparatus not yet ideal, (6) Unfavorable performance accountability, (7) The quality of public services is still low.

The problems that often arise in the enforcement of the Civil State Apparatus
Law as follows;

Inevitably, likes or not, the law is the main pillar, then it is appropriate if the policy direction must be bundled with bureaucratic reform in accordance with RPJM 2015-2019. What then underlies legally so it needs to be answered with strong resolutions and can be done properly and correctly. First there should be an area that is completely revamped and overhauled. Secondly there must be a target of accountability, transparency and unlawful.

Areas to work are; mental apparatus, state institutions, governance, human resources apparatus, Accountability, Supervision, Legislation, and improvement of public services. The strong target is for the realization of a clean, accountable, effective-efficient, and top-quality bureaucracy in public service. ${ }^{26}$

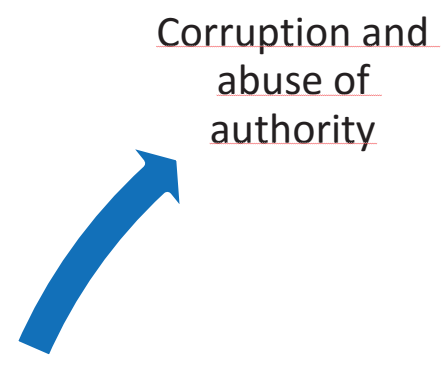

the low of public services

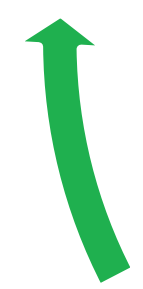

Bad accountability
Overlaping Regulation

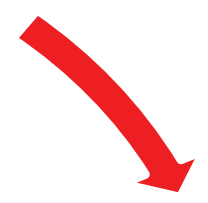

Overlaping

Authority

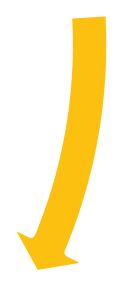

un-

propoltional

organization

un-ideal of Human

resourse both

quantity and quality

26 Kementerian Pendayagunaan Aparatur Negara Dan Reformasi Birokrasi, Revolusi Mental ASN dan UU ASN, Jakarta, 18 Mei 2016 


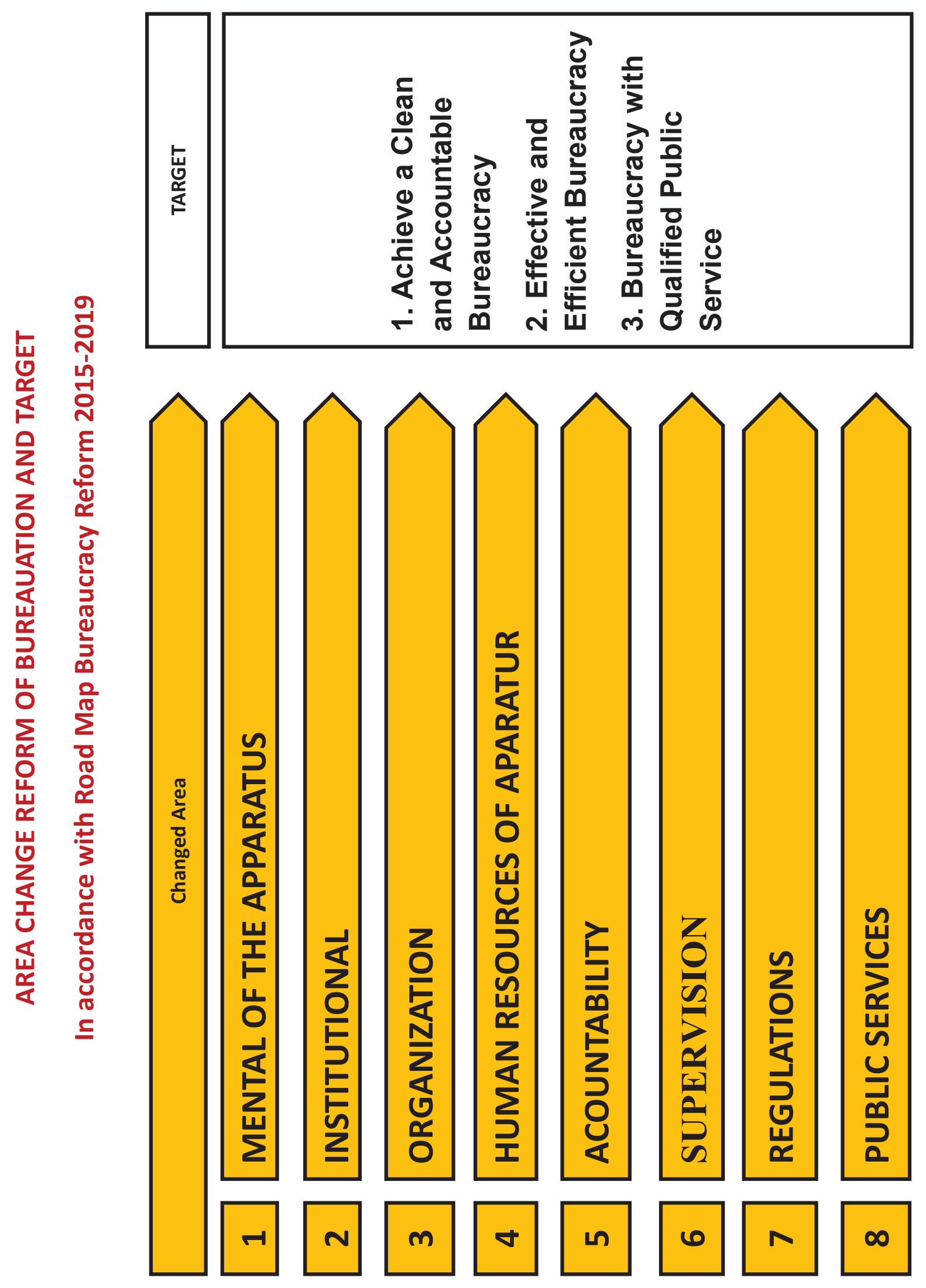


There is a crucial point in terms of legislation that is the application of merit system. The State Civil Apparatus Act ${ }^{27}$ (ASN) number 5 of 2014 signed on 15 January 2014. It has changed the paradigm that has been attached to civil servants. Previous civil servants consist of central, regional and PTT, in addition there are Indonesian Army civil servants and Police. With the enactment of this ASN there are only 2 types of employees as elements of the state apparatus, the Civil Servants of the Republic of Indonesia (PNS) and Government Employees with Work Agreement (PPPK). There is also a change in the retirement age of civil servants from 55 years to 58 years.

Productive age does not become one of the legal benchmark in carrying out government performance and able to be the latest breakthrough. However, that alone is not enough when the age becomes the measure of a performance success in the legal context. It must balance with the decomposition of other problems and is based on the government performance road map from 2015 to 2019.

\section{Conclusion}

Nawacita in the context of its legal regulation is not the most perfect product. It is a work of ordinary man who could have been exploited for the benefit of politics and other agendas. Regardless of that, the Civil State's Apparatus law means the extent to which the success of bureaucracy reform is successful, and the continuity between the implemented law and the law being merely a "signboard".

Structuring the law in the context of staffing becomes increasingly comparable from the competence that should be owned by the government apparatus that runs the duty to serve the people. ${ }^{28}$ This is not in line with the position and role of Civil Servants as an element of the State Apparatus who served as a public servant who must carry out the functions of

27 The Merit System is a policy and HR management Apparatus based on qualifications, competence and performance fairly and fairly, without distinction of political background, race, color, religion, origin, sex, marital status, age, or disability.

28 Sri Martini, SH.MH, Hj. Setiajeng Kadarsih, SH.MH dan Tedi Sudrajat, SH, Hukum Kepegawaian di Indonesia, Sinar Grafika, Jakarta, 2008, p. 1 government well through the implementation of services fairly and equitably to the community based on loyalty and obedience to Pancasila and the 1945 Constitution of the State.

The enactment of Law Number 22 Year 1999 regarding Regional Government is the result of reform demands against Law Number 5 Year 1974 on the Principles of Government in the Region and Law Number 5 Year 1999 on Village Government, bringing the consequences of changes in the political, economic and social which is so fast, including employment issues. ${ }^{29}$

Bureaucracy reform in the field of personnel is marked by the enactment of Law No. 43 of 1999 on the Amendment of the Civil Service Act which is a change and refinement of Law Number 8 Year 1974 . Then followed by various implementation regulations, whether in the form of Government Regulation (PP) and the Presidential Decree (Keppres), to ensure the implementation of Law Number 43 Year 1999 is well and directed. ${ }^{30}$

Referring to the Law of the Republic of Indonesia Number 5 Year 2014 on State Civil Apparatus; that how the agenda of change of Civil State Apparatus law related to bureaucracy reform is not silent because some of accountancy and staff corruption problem and so on. It always runs the legal preparedness in facing the increasingly tapered legal challenges. Arranging a law-based bureaucracy, arrange the state power pillared on the performance aspect of the Civil State Apparatus is not easy but it is also impossible, we cannot fix together. If nawacita is a tool of pruning lies and ignorance of the law in the implementation Jokowi-JK government journey then legitimate and may be perpetuated. But it must first be proved by the people that the law and the jaws are really synergies and produce results according to the RPJM 2015-2019.

The sound of Law Number 5 Year 2014 is; "That the implementation of civil state apparatus management has not been based

29 Made Suwandi, Agenda Kebijakan Reformasi Pemerintahan Daerah, Badan Litbang Depdagri, Jakarta, 2001, p.9.

30 Komang Rai Sudjaka, Wewenang Kepala Daerah dalam Pengangkatan dan Pemberhentian Pegawai Negeri Sipil untuk Jabatan Struktural, Tesis, Program Pascasarjana Fakultas Hukum Universitas Udayana, Denpasar, 2004, p. 2. 
on the comparison between the competencies and qualifications required by the position with the competencies and qualifications of the candidates in the recruitment, appointment, placement and promotion of the position in line with good governance";

\section{BIBLIOGRAPHY}

Afadlal (Ed.), Dinamika Birokrasi Lokal Era Otonomi Daerah, Jakarta: P2P LIPI,2003.

Hans-Dieter Evers dan Tilman Schiel, Kelompok-Kelompok Strategis: Studi Perbandingan tentang Negara, Birokrasi, dan Pembentukan Kelas di Dunia Ketiga, Jakarta: Yayasan Obor Indonesia, 1990, hal, 228.

Kementerian Pendayagunaan Aparatur Negara Dan Reformasi Birokrasi, Revolusi Mental ASN dan UU ASN, Jakarta, 18 Mei 2016

Komang Rai Sudjaka, Wewenang Kepala Daerah dalam Pengangkatan dan Pemberhentian Pegawai Negeri Sipil untuk Jabatan Struktural, Tesis, Program Pascasarjana Fakultas Hukum Universitas Udayana, Denpasar, 2004

Lawrence M. Friedman, American Law: An Introduction, New York: W.W. Norton, 1998

Lili Romli, "Otonomi Daerah dan Birokrasi Lokal: Kasus Kabupaten Pandeglang" dalam Syamsuddin Haris, "Sentralisasri Baru Dalam Birokrasi Lokal:Kasus Kabupaten Bima", dalam, Afadlal,(Ed.),Dinamika Birokrasi Lokal Era Otonomi Daerah, Jakarta: P2P LIPI,2003, hal. 64.

Lili Romli, Masalah Reformasi Birokrasi, Jurnal Kebijakan dan Manajemen PNS, Vol. 2 November 2008.

Made Suwandi, Agenda Kebijakan Reformasi Pemerintahan Daerah, Badan Litbang Depdagri, Jakarta, 2001

Menpan: RUUAdiministerasi Pemerintahan Pryasyarat Reformasi Birokrasi", dikutip dai http://www. gtzsfgg.or.id/index.php?page=menpan-ruu-administrasi Pemerintahan-prasyaratreformasi- birokrasi\&hl=en_EN, accessed on14 Januari 2017 pukul 16.40 wib.

Peratutan Presiden Nomor 60 Tahun 2105 Tentang Rencana Kerja Pemerintah Tahun 2016, Tema : Mempercepat Pembangunan Infrastruktur Untuk Memperkuat Fondasi Pembangunan Yang Berkualitas, p. 1-1

Peraturan Presiden Nomor 24 Tahun 2010 tentang Kedudukan, Tugas, dan Fungsi Kementerian Negara serta Susunan Organisasi, Tugas, dan Fungsi Eselon I Kementerian Negara

Peraturan Presiden Nomor 56 tahun 2013 tentang Perubahan ke empat atas Peraturan Presiden Nomor 24 Tahun 2010 tentang Kedudukan, Tugas, dan Fungsi Kementerian Negara serta Susunan Organisasi, Tugas, dan Fungsi Eselon I Kementerian Negara.

Saldi Isra, Hukum Yang Terabaikan, Kompas, 22 Juli 2016

Saldi Isra, Mempercepat Agenda Hukum, Kompas 21 Oktober 2016.

Sri Martini, SH.MH, Hj. Setiajeng Kadarsih, SH.MH dan Tedi Sudrajat, SH, Hukum Kepegawaian di Indonesia, Sinar Grafika, Jakarta, 2008, p. 1

Visi Misi Capres-Cawapres Joko Widodo - Jusuf Kalla ketika mendaftarkan diri ke KPU. Dimuat dalam http://kpu.go.id/koleksigambar/VISI_MISI_Jokowi-JK.pdf, accessed on 5 Mei 2015 
Wahyudi Djafar, Menjejaki Kembali Problematika Hukum Indonesia, dalam Asasi Elsam, November-Desember 2010.

Zainal Abidin, Catatan Elsam Terkait RPJMN 2015-2019 Di Bidang Hukum Dan HAM, 11 Nopember 2015, dalam http://elsam.or.id/2015/03/catatan-elsam-terkait-rpjmn-20152019-di-bidang-hukum-dan-ham/ accessed on14 Januari 2017 at 12.15 wib

http://www.kompasiana.com/rickoricardo/keberhasilan-nawacita-jokowi-jk-satu-tahun-pemerintahan_562cb5dbd27a6141076e3fb1, accessed on 14 Januari 2017 at 11.15 wib.

https://polkam.go.id/perwujudan-nawacita-di-bidang-politik-hukum-dan-keamanan-untuk-memulihkan-kepercayaan-publik-memberikan-keadilan-dan-kepastian-hukum/ accessed on 14 Januari 2017 at 11.26 wib.

http://www.hukumonline.com/berita/baca/lt5805f6a92b7b4/dua-tahun-jokowi-jk--hukum-terabaikan, accessed on14 Januari 2017 at 11.26 wib.

Nawacita dan RPJMN sebagai Kesatuan Rencana Pembangunan: Bidang Hukum HAM, dipersiapkan oleh Lembaga Studi dan Advokasi Masyarakat (Institute for Policy Research and Advocacy) pada 11 Maret 2015.

http://www.infonawacita.com/2-tahun-nawacita-memberikan-keadilan-dan-kepastian-hukum/ accessed on 14 Januari 2017 at 14.36 wib. 